\title{
Toward a Framework for Cooperation Behavior of Start-Ups: Developing a Multi-Item Scale from an Empirical Perspective
}

\author{
Konstantin Garidis \\ Reutlingen University \\ konstantin.garidis@student.reutlingen-university.de
}

\author{
Alexander Rossmann \\ Reutlingen University \\ alexander.rossmann@reutlingen-university.de
}

\begin{abstract}
Many start-ups are in search of cooperation partners to develop their innovative business models. In response, incumbent firms are introducing increasingly more cooperation systems to engage with start-ups. However, many of these cooperations end in failure. Although qualitative studies on cooperation models have tried to improve the effectiveness of incumbent start-up strategies, only a few have empirically examined start-up cooperation behavior. Considering the lack of adequate measurement models in current research, this paper focuses on developing a multi-item scale on cooperation behavior of start-ups, drawing from a series of qualitative and quantitative studies. The resultant scale contributes to recent research on start-up cooperation and provides a framework to add an empirical perspective to current research.
\end{abstract}

\section{Introduction}

Cooperations between start-ups and incumbent firms are common because they help increase an incumbent's innovation effectiveness [15] and a startup's corporate performance [31]. Entrepreneurial firms, which often lack sufficient resources, profit from partner experiences, existing networks, customer relationships, and also resources to develop their hypothetical business models [5, 24]. Conversely, incumbent firms often seek innovation advantages to exploit existing business models in cooperation with start-ups [4]. Different models exist on how a cooperation between incumbents and start-ups can be executed from an organizational perspective [33]. Therefore, a wealth of research has explored how such cooperations are organized and which implications accompany such models $[4,8,19,21,33]$.

These studies have identified several models of interfirm cooperation that are specific to a start-up and incumbent relationship. For example, Weiblen and Chesbrough [33] identify four organizational engagement models and their implications. Moreover, other research has focused on one specific model-for example, an accelerator and its characteristics (e.g. [17, 18, 21]). This paper uses the term "cooperation" to describe different cooperation models and does not limit the term to a specific type of cooperation. While most of the aforementioned studies use qualitative research methods, fewer studies in the current research area use quantitative empirical methods to analyze the different aspects of cooperation between start-ups and incumbents; rather, most studies use economic data to analyze various impacts of start-ups' cooperation engagement $[5,15,26]$.

Given the lack of empirical evidence in the field, adequate measurement models that enable researchers to quantify different aspects of a start-up's cooperation behavior are missing [25]. Therefore, this research paper focuses on a systematic approach to develop a multi-item scale to evaluate start-ups' cooperation behavior and the impact of such behavioral patterns on start-up performance. After identifying the relevant aspects of cooperation behavior, the item development process derives three dimensions for start-ups' cooperation behavior (intention to cooperate, cooperation intensity, and cooperation quality) and one dimension of start-up performance. Moreover, the results of this research provide evidence for the impact of start-up cooperation behavior on start-up performance. The scale development process contributes to current cooperation research and fills the gap of missing empirical studies on the relationship between start-ups and incumbents.

\section{Theory and literature review}

\subsection{Start-ups and cooperation}

A start-up's objective is not to execute an existing business model but to develop a new one. The entrepreneur Steve Blank defines a start-up as "a temporary organization designed to search for a repeatable and scalable business model" [28]. Start-ups usually do not have an existing network in the market and lack abundant resources to develop their business 
model ideas. Therefore, they rely on established partners and investors, which also can be cooperation partners [31, 33].

Rather than focusing on a specific cooperation model as mentioned previously, this paper develops a multi-item scale that can be used for all types of cooperations between start-ups and incumbent firms. Thus, the scope of this research is based on the uneven relationship between a small, entrepreneurial firm and its larger and established partners. Such relationships have different aspects that previous research has addressed [14, 20]. Other than being small and medium-sized enterprises, start-ups are bound by the liability of newness [31]. Depending on its purpose as an organization, a start-up's main goal is to explore a new niche or even build a new market, while an established firm's goal is more often to exploit existing markets [4]. Consequently, although partners in such relationships follow the same goal within the scope of their cooperation, they might follow different longtime goals, which ultimately might lead to an unspoken conflict of interest. Therefore, the behavior during the cooperation and the intention toward cooperations could fundamentally differ [15].

This discussion leads to the hypothesis that a startup's cooperation behavior is an important dimension of cooperation performance between it and its established partner firms. Given this assumption, a measurement model addressing a start-up's cooperation behavior is essential for current cooperation research.

\subsection{Related Research}

In preparation for the development of a measurement model, a systematic literature analysis [27] was conducted. To ensure reliable identification of missing measurement models in extant research, the review approach of Webster and Watson [32] describing essential steps was executed in three steps: (1) search strategy: identifying relevant search strings and databases; (2) evaluation: removing duplicate and irrelevant articles through a title and abstract review; and (3) reading: full text reading and backward search.

Table 1 shows the selection and evaluation process. The literature search was conducted in four databases, including ACM, ScienceDirect, Academic Search Premier, and Emerald Insight, and only peer-reviewed articles were considered. With the few results found, there was no time limitation implemented in the search. Table 3 lists the identified articles and the six studies that are identified as most relevant (highlighted in gray). The studies are classified into three categories. The first, cooperation models, includes studies that focus on evaluating a specific cooperation model or a type of cooperation model (e.g. Weiblen and Chesbrough [33] focus on analyzing corporate start- ups). The second, requirements for cooperation, includes studies that focus on factors that are relevant before entering a cooperation (e.g. Das and He [6] focus on analyzing partner selection criteria of startups). The third category, performance, includes studies that focus on start-up performance in the context of alliances or cooperations or in collaboration with other market participants (e.g. Islam et al. [15] focus on increasing digital innovation performance through inter-organizational collaboration).

Table 1 Literature review process

\begin{tabular}{|c|c|c|}
\hline \multirow{5}{*}{$\begin{array}{l}\text { Phase 1: } \\
\text { Search } \\
\text { strategy }\end{array}$} & \multicolumn{2}{|l|}{ Search strings } \\
\hline & \multicolumn{2}{|l|}{ "start-up" + cooperation } \\
\hline & \multicolumn{2}{|c|}{ corporate + "start-up" } \\
\hline & \multicolumn{2}{|c|}{ Start-up, interfirm, cooperation } \\
\hline & \multicolumn{2}{|c|}{ "start-up" + performance } \\
\hline \multirow{4}{*}{$\begin{array}{l}\text { Phase 2: } \\
\text { Evaluation }\end{array}$} & \multirow[t]{2}{*}{ Database search } & $\begin{array}{l}\text { Preliminary } \\
\text { articles }\end{array}$ \\
\hline & & 1025 \\
\hline & \multirow{2}{*}{$\begin{array}{l}\text { Removing duplicate } \\
\text { and non-relevant } \\
\text { articles }\end{array}$} & Remaining articles \\
\hline & & 30 \\
\hline \multirow{4}{*}{$\begin{array}{l}\text { Phase 3: } \\
\text { Reading }\end{array}$} & \multirow{2}{*}{$\begin{array}{l}\text { Full text reading and } \\
\text { backward search }\end{array}$} & Remaining articles \\
\hline & & 20 \\
\hline & \multirow[t]{2}{*}{ Most relevant articles } & Identified articles \\
\hline & & 6 \\
\hline
\end{tabular}

\subsection{Synthesis}

While all 20 articles investigate cooperation as it is considered in the current paper, the six identified articles show the highest relevance in terms of their research focus.

Colombo et al. [5] focus on complementary assets in distinguishing exploitative and explorative cooperations. Although the study employs an empirical approach, the authors use data from an existing database about start-ups from Italy. They analyze different factors influencing the start-ups' cooperation activities. For example, they find that patent holding has a significant influence on the number of commercial alliances.

Das and He [6] provide a list of recommendations that assist entrepreneurial firms in selecting established firms as alliance partners. They explicitly distinguish between start-ups and established firms to build their model. Their model is based on an extensive literature review and illustrating cases of successful and unsuccessful collaborations.

Islam et al. [15] conduct 30 qualitative interviews with established firms and start-ups to identify different factors of the firms' intentions toward cooperations and their actual cooperation behavior. They find that incumbents' intentions include a focus on increasing innovation performance and start-ups' velocity and gaining access to digital knowledge. By 
contrast, start-ups tend to focus on gaining access to required resources. Furthermore, collaboration behavior of the established firms is influenced by culture clash, one-sided power relations, or the unrealistic conception of start-ups, while start-ups perceive collaborations as also being influenced by unequal power relations, lack of seriousness toward start-ups, limited market experience, and high digital knowledge.

Oukes and Von Raesfeld [20] observe a single start-up and its key partners during 18 interaction periods. They show that partners' actions are influenced by events from previous periods. This indicates that entrepreneurial firms can actively influence behavior in future periods by actively considering their actions.

Rothaermel [26] assesses the criteria that established firms in the biotechnology sector use to choose their alliance partners from new market entrants. They find that greater new product development, economies of scope, and the start-up's location significantly and positively influence the attractiveness of an alliance partner.

Weiblen and Chesbrough [33] use several case studies to analyze the concept of the corporate start-up as a driver of innovation. In doing so, they focus on the innovation process of incumbent firms rather than on start-ups specifically. Nonetheless, their research provides different models for corporate start-ups and their implications.

\subsection{Results of literature review}

The results show that eight of the identified studies are of an empirical nature. While six of the studies draw their data from existing databases or other publicly available sources, only two studies use a questionnaire to collect data. Dowling and Helm [7] focus on economic data from entrepreneurial firms and other cooperation measures but avoid using multi-item scales for data collection. Among the research articles, only Tomlinson [30] uses a multi-item measurement model to analyze the impact of cooperations on product innovation, though he does not necessarily focus on start-ups.

While various studies have considered the cooperation between start-ups and established partners, most of the relevant articles focus on qualitative methods. However, the empirical studies largely employ data from existing databases or avoided using multi-item scales, while no study has tried to measure start-ups' cooperation behavior in a multi-item scale. This suggests that a development process for start-ups' cooperation behavior is necessary.

\section{Development of a measurement scale on start-up cooperation behavior}

\subsection{Study overview}

The following process follows well-accepted scale development procedures [10] as illustrated by multiple authors [1, 23]. Table 2 summarizes the development process.

The process is divided in three stages. The first stage (phases 1 and 2) consists of two qualitative studies to identify the constructs' dimensions and find suitable adjectives describing the dimensions. The second stage (phase 3 ) involves a quantitative study to evaluate the degree to which the identified adjectives are suitable to describe the construct dimensions. From these results, the preliminary measurement model is constructed. The third stage (phase $4 \mathrm{a}$ and $4 \mathrm{~b}$ ) tests the developed measurement model for its validity and reliability as well as their causal effects. This is achieved through a standardized online survey that collected data from 49 start-up executives.

Table 2 Overview of development process

\begin{tabular}{|l|l|l|l|}
\hline Phase & Objective & Sample/Method & Finding \\
\hline 1 & Definition of dimensions & $\begin{array}{l}\text { Semi-structured qualitative } \\
\text { interviews with three scholars }\end{array}$ & $\begin{array}{l}\text { Three behavior dimensions } \\
\text { of start-up cooperation and } \\
\text { one performance dimension }\end{array}$ \\
\hline 2 & Identification of adjectives & $\begin{array}{l}\text { Three workshops with 22 } \\
\text { working students adjectives }\end{array}$ \\
\hline 3 & Reducing of items & $\begin{array}{l}\text { Item reduction based on 20 adjectives, 5 for each } \\
\text { rating from students }\end{array}$ & $\begin{array}{l}\text { Online survey questioning 49 } \\
\text { dimension }\end{array}$ \\
\hline 4 & Validation of scale & $\begin{array}{l}\text { Sample data used to estimate } \\
\text { validity and reliability and } \\
\text { causal effects of the model }\end{array}$ \\
\hline
\end{tabular}


Table 3 Identified papers of literature review

\begin{tabular}{|c|c|c|c|c|c|c|}
\hline Author & Year & Journal & Type & Cooperation Model & $\begin{array}{l}\text { Requirements } \\
\text { for Cooperation }\end{array}$ & Performance \\
\hline $\begin{array}{l}\text { Buckley and } \\
\text { Prashantham [4] }\end{array}$ & 2016 & $\begin{array}{l}\text { Academy of } \\
\text { Management } \\
\text { Perspectives } \\
\end{array}$ & Conceptual & $\checkmark$ & & \\
\hline $\begin{array}{l}\text { Minshall et al. } \\
\text { [19] }\end{array}$ & 2008 & $\begin{array}{l}\text { Journal of } \\
\text { Manufacturing } \\
\text { Technology } \\
\text { Management }\end{array}$ & Qualitative & $\checkmark$ & & \\
\hline $\begin{array}{l}\text { Colombo et al. } \\
\text { [5] }\end{array}$ & 2006 & Research Policy & Empirical & $\checkmark$ & & \\
\hline Das and $\mathrm{He}[6]$ & 2006 & $\begin{array}{l}\text { International } \\
\text { Journal of } \\
\text { Entrepreneurial } \\
\text { Behavior \& } \\
\text { Research }\end{array}$ & Case study & & $\checkmark$ & \\
\hline Di Berardino [2] & 2016 & $\begin{array}{l}\text { Procedia } \\
\text { Economics and } \\
\text { Finance } \\
\end{array}$ & Empirical & & & $\checkmark$ \\
\hline $\begin{array}{l}\text { Dowling and } \\
\text { Helm [7] }\end{array}$ & 2006 & Technovation & Empirical & & & $\checkmark$ \\
\hline Edison et al. [8] & 2018 & $\begin{array}{l}\text { Journal of } \\
\text { Systems and } \\
\text { Software }\end{array}$ & Qualitative & $\checkmark$ & & \\
\hline Faria et al. [9] & 2010 & Research Policy & Empirical & $\checkmark$ & & $\checkmark$ \\
\hline $\begin{array}{l}\text { Hagedoorn et al. } \\
\text { [11] }\end{array}$ & 2017 & $\begin{array}{l}\text { Small Business } \\
\text { Economics }\end{array}$ & Empirical & & & $\checkmark$ \\
\hline $\begin{array}{l}\text { Hockerts and } \\
\text { Wüstenhagen } \\
{[14]}\end{array}$ & 2010 & $\begin{array}{l}\text { Journal of } \\
\text { Business } \\
\text { Venturing } \\
\end{array}$ & Conceptual & & & $\checkmark$ \\
\hline Islam et al. [15] & 2017 & $\begin{array}{l}\text { ECIS } 2017 \\
\text { Proceedings }\end{array}$ & Qualitative & $\checkmark$ & & $\checkmark$ \\
\hline $\begin{array}{l}\text { Kim and } \\
\text { Wagman [16] }\end{array}$ & 2014 & $\begin{array}{l}\text { Journal of } \\
\text { Corporate Finance }\end{array}$ & Empirical & $\checkmark$ & & \\
\hline Kohler [17] & 2016 & $\begin{array}{l}\text { Business } \\
\text { Horizons }\end{array}$ & Qualitative & $\sqrt{ }$ & & \\
\hline Malek et al. [18] & 2014 & $\begin{array}{l}\text { Journal of } \\
\text { Engineering and } \\
\text { Technology } \\
\text { Management }\end{array}$ & Empirical & $\checkmark$ & & \\
\hline $\begin{array}{l}\text { Oukes and Von } \\
\text { Raesfeld [20] }\end{array}$ & 2016 & IMP Journal & Conceptual & & & \\
\hline $\begin{array}{l}\text { Pauwels et al. } \\
\text { [21] }\end{array}$ & 2016 & Technovation & Case study & $\checkmark$ & & \\
\hline Perez et al. [22] & 2013 & $\begin{array}{l}\text { European Journal } \\
\text { of Marketing }\end{array}$ & Qualitative & $\checkmark$ & & $\checkmark$ \\
\hline Rothaermel [26] & 2002 & $\begin{array}{l}\text { IEEE } \\
\text { Transactions on } \\
\text { Engineering } \\
\text { Management }\end{array}$ & Qualitative & & $\checkmark$ & $\checkmark$ \\
\hline Tomlinson [30] & 2010 & Research Policy & Empirical & & & $\checkmark$ \\
\hline $\begin{array}{l}\text { Weiblen and } \\
\text { Chesbrough } \\
{[33]}\end{array}$ & 2015 & $\begin{array}{l}\text { California } \\
\text { Management } \\
\text { Review }\end{array}$ & Qualitative & $\checkmark$ & & $\checkmark$ \\
\hline
\end{tabular}


Table 4 Translated items

\begin{tabular}{|c|c|c|c|}
\hline Dimension & No. & Translated Items & Scale (financial scales in USD) \\
\hline \multirow[t]{5}{*}{$\begin{array}{l}\text { Intention to } \\
\text { cooperate }\end{array}$} & 1 & $\begin{array}{l}\text { We (as a start-up) are curious to exchange } \\
\text { knowledge and experience with other } \\
\text { companies. }\end{array}$ & \multirow{5}{*}{$\begin{array}{l}\text { "Strongly disagree" } \\
\text { "Disagree" } \\
\text { "More or less disagree" } \\
\text { "Undecided" } \\
\text { "More or less agree" } \\
\text { "Agree" } \\
\text { "Strongly agree" }\end{array}$} \\
\hline & 2 & We are open to discuss potential cooperations. & \\
\hline & 3 & $\begin{array}{l}\text { We are not critical of sharing information with } \\
\text { other market participants. }\end{array}$ & \\
\hline & 4 & $\begin{array}{l}\text { In general, we are interested in co-operating } \\
\text { with other companies. }\end{array}$ & \\
\hline & 5 & $\begin{array}{l}\text { We are open to try new approaches with our } \\
\text { partners. }\end{array}$ & \\
\hline \multirow{6}{*}{$\begin{array}{l}\text { Cooperation } \\
\text { intensity }\end{array}$} & 1 & We have trust in our partners' reliability. & \multirow{6}{*}{$\begin{array}{l}\text { "Strongly disagree" } \\
\text { "Disagree" } \\
\text { "More or less disagree" } \\
\text { "Undecided" } \\
\text { "More or less agree" } \\
\text { "Agree" } \\
\text { "Strongly agree" }\end{array}$} \\
\hline & 2 & $\begin{array}{l}\text { How often do you hold meetings with you } \\
\text { partners? }\end{array}$ & \\
\hline & 3 & $\begin{array}{l}\text { Each of our partnerships consists of a clear } \\
\text { target. }\end{array}$ & \\
\hline & 4 & $\begin{array}{l}\text { Feedback is an inherent part of our } \\
\text { partnerships. }\end{array}$ & \\
\hline & 5 & $\begin{array}{l}\text { Our infrastructure is built to quickly integrate } \\
\text { new partners. }\end{array}$ & \\
\hline & 6 & $\begin{array}{l}\text { The added value for our customers depends on } \\
\text { our partners. }\end{array}$ & \\
\hline \multirow{5}{*}{$\begin{array}{l}\text { Cooperation } \\
\text { quality }\end{array}$} & 1 & We highly trust our partners. & \multirow{5}{*}{$\begin{array}{l}\text { "Strongly disagree" } \\
\text { "Disagree" } \\
\text { "More or less disagree" } \\
\text { "Undecided" } \\
\text { "More or less agree" } \\
\text { "Agree" } \\
\text { "Strongly agree" }\end{array}$} \\
\hline & 2 & $\begin{array}{l}\text { Our partners promote the development of our } \\
\text { products and services. }\end{array}$ & \\
\hline & 3 & $\begin{array}{l}\text { We also support our partners in critical } \\
\text { situations. }\end{array}$ & \\
\hline & 4 & $\begin{array}{l}\text { We as well as our partners describe our co- } \\
\text { operation as a success. }\end{array}$ & \\
\hline & 5 & We depend on our partners' expertise. & \\
\hline \multirow[t]{7}{*}{ Performance } & 1 & Revenue & 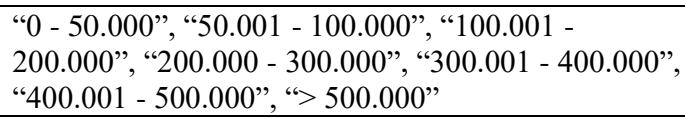 \\
\hline & 2 & Month of first revenue & Month of first revenue as a number \\
\hline & 3 & Profit or loss & "Profit", "Loss", "Neither" \\
\hline & 4 & Amount of profit or loss & 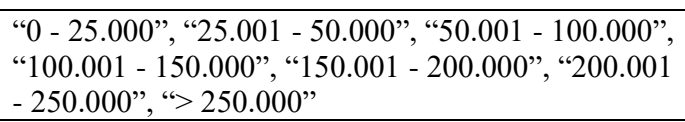 \\
\hline & 5 & Product time to market & $\begin{array}{l}\text { "We are not on the market yet", "Before founding", } \\
\text { "After a few months", "After under a year", "After } \\
\text { more than a year"," After more than two years", "I'm } \\
\text { not sure" }\end{array}$ \\
\hline & 6 & Number of customers & 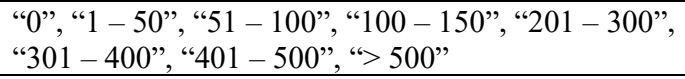 \\
\hline & 7 & Amount of external investment & $\begin{array}{l}\text { "none", ,1 - 5.000", "5.001 - 10.000", "10.001 - } \\
50.000 ", " 50.001-100.000 ", " 100.001-300.000 ", \\
\text { "300.001 - 500.000", "500.001 - 1.000.000", } \\
\text { "1.000.001 - 3.000.000", "3.000.001 - 5.000.000", "> } \\
\text { 5.000.000", "I don't know" }\end{array}$ \\
\hline
\end{tabular}




\subsection{Phase 1: Definition of dimensions}

Phase 1 serves to identify relevant dimensions of a start-up's cooperation behavior. This is based on the conducted research described in section 2 and semistructured qualitative interviews with three scholars. The scholars were asked how to measure start-ups' cooperation behavior. They identified and described three dimensions for start-up behavior supplemented by a fourth performance dimension.

Intention to cooperate is the basic attitude a start-up has toward potential cooperations. More specifically, it measures the mindset of a start-up with regard to cooperations before entering them.

Cooperation intensity is the degree to which cooperation is a fundamental part of a start-up's daily business. Start-ups with a high cooperation intensity rely on and invest a significant proportion of their resources in their cooperations (for most start-ups, their personnel is their most valuable resource).

Cooperation quality considers the possibility that an intense cooperation is not always of high quality. A start-up's behavior can influence the cooperation quality, for example, by withholding relevant information from its partners because of a lack of trust. Therefore, cooperation quality measures the extent of the quality of a start-up's cooperation.

Start-up performance represents the measurement of firm performance from a start-up perspective. Firm performance is typically measured by indicators like revenue or profit. Many start-ups, especially in an early stage, don't make any profit by design. Therefore, start-up performance might be measured by different attributes like the amount of investment by third parties, revenue growth, number of employees or number of customers/users. Consequently, start-up performance need to be measured by a multi-item scale.

\subsection{Phase 2: Identification of adjectives used to describe the relevant dimensions}

While phase 1 identified the dimensions of cooperation behavior, phase 2 is designed to find suitable adjectives that help describe the dimensions. These adjectives can later be used to build multiple items for each dimension. Therefore, three workshops with master's students of managing information systems were held at a German university. The students all work full-time in either IT firms or in the IT department of a firm and study part-time.

The students were handed a printout on which each dimension was briefly described, and examples of possible answers were provided as a guideline. The students had 15 minutes time to complete the questionnaire. At the end of the questionnaire, the students had the possibility to give feedback on the comprehensiveness of the task.

In total, 22 students filled out the survey, providing 345 adjectives that describe the four dimensions. Before the next phase began, the adjectives were sorted and consolidated. This sorting followed three steps: (1) removing duplicates, (2) consolidating synonyms and adjectives that describe the same factor, and (3) sorting the adjectives in terms of their mentioned count and relevance. After these steps, at least 12 adjectives for each dimension that can be potentially used to build items could be identified.

\subsection{Phase 3: Quantitative screening of factors}

Phase 3 identifies potential factors by screening the previously collected adjectives with a standardized online survey. In total, 79 students from a German university took part in the online survey. The participants were asked to rank each adjective by its qualification to describe the respective dimension. They were provided 7-point Likert-type scales (1 = "not at all suitable," $7=$ "entirely suitable"). According to the evaluations, five adjectives per dimension were picked for the next phase. The evaluation was measured according to the mean for each adjective.

\subsection{Phase 4a: Measurement model building and validation survey}

In phase 4 , the identified adjectives were used to formulate items. Accordingly, each dimension was now described by five items. As in the previous phases, data were conducted in German so the items needed to be translated. To ensure a subjective translation, an independent foreign language correspondence clerk translated the items into English. After the translation, the items were verified. Table 4 shows the final items and their respective scale used in the validation survey. 
Finally, a validation online survey was conducted. The survey questioned 49 founders (31), CEOs (11), and executives (7) of start-ups based in Germany. As the largest group, $38.8 \%$ of the start-ups were based in the software and IT industry. The others were spread across several industries such as finance and retail. The start-ups had 16.4 employees on average, while only one start-up stated that it had more than 100 people employed. With regard to product type, $51 \%$ of the start-ups offer a service, while the others offer a physical product $(16.3 \%)$, both a service and a product $(14.3 \%)$, or software (18.3\%). In addition, $46.9 \%$ of the questioned start-ups serve business customers, $12.2 \%$ serve consumers only, and $40.8 \%$ serve both. As 25 of the start-ups are still incurring a loss and only 18 are making a profit (10 with 25,000 USD or less), the firms in question are not quite established market entries.

\subsection{Phase 4b: Measurement model assessment and causal effects}

The collected data can now be used to assess the conceptualized measurement model with regard to the items' validity and reliability. Therefore, we applied a confirmatory factor analysis (CFA) with smartPLS (v. 3.2.7) on the data set. Before the full analysis, an item purification process was conducted to omit items with low loadings. The main criterion is the loading of the item onto its respective construct, which should be higher than or equal to 0.5 [12]. Through this process, the following items were omitted in this study: Intensity_5, Intensity_6 and performance_2 to performance_5.

The CFA provides sufficient support for the applied factor structure. Table 5 shows the relevant indicators to assess the constructs' reliability and validity. According to Hair et al.'s [12] recommendations, Cronbach's alpha (threshold higher than 0.7), composite reliability (threshold higher than 0.7 ), and average variance extracted (threshold higher than 0.5) are all valid.

Table 5 Construct reliability and validity

\begin{tabular}{|l|l|l|l|}
\hline & $\begin{array}{l}\text { Cronbach's } \\
\text { Alpha }\end{array}$ & $\begin{array}{l}\text { Composite } \\
\text { Reliability }\end{array}$ & $\begin{array}{l}\text { Average } \\
\text { Variance } \\
\text { Extracted }\end{array}$ \\
\hline $\begin{array}{l}\text { Intention to } \\
\text { cooperate }\end{array}$ & 0.847 & 0.891 & 0.622 \\
\hline $\begin{array}{l}\text { Cooperation } \\
\text { intensity }\end{array}$ & 0.717 & 0.826 & 0.552 \\
\hline $\begin{array}{l}\text { Cooperation } \\
\text { quality }\end{array}$ & 0.774 & 0.847 & 0.531 \\
\hline $\begin{array}{l}\text { Startup } \\
\text { performance }\end{array}$ & 0.834 & 0.900 & 0.751 \\
\hline
\end{tabular}

Also according to Hair et al. [12], discriminant validity can be assessed on the basis of the crossloadings and the Fornell-Larcker criterion. All loadings correlate the most with their respective construct. Intensity_4 shows a relatively high correlation with intention to cooperate. Therefore, the item should be observed closely in further research. As the Fornell-Larcker criterion listed in Table 6 shows, the criterion confirms the discriminant validity. Again, intention to cooperate and cooperation intensity seem rather close and should be observed in future research.

In addition to the measurement model assessment, we conducted a test of the causal relationship between (1) intention to cooperate, (2) cooperation intensity, and (3) start-up performance. Based on the bootstrapping properties of the PLS-SEM algorithm, calculations with small sample sizes are valid on small models [13]. Thus, we were able to estimate a simple linear model. We analyzed the effect of intention to cooperate on cooperation intensity and the effect of cooperation intensity on start-up performance. The results of the PLS analysis confirm a causal relationship between the examined constructs. The path coefficient from intention to cooperate to cooperation intensity is high with $\beta=.689$. Average variance extracted shows an $\mathrm{R}^{2}$ of .475 . Thus, a significant part of cooperation intensity is explained by intention to cooperate. Moreover, the path coefficient from cooperation intensity to start-up performance is also relevant with $\beta=.211$. However, average variance extracted of start-up performance shows $\mathrm{R}^{2}=.044$. This leads to the observation, that there is indeed a causal relationship between the behavioral dimensions of a start-up, which further validates the measurement model. An analysis of the differentiated effects of cooperation intensity on performance under different moderating circumstances might be a subject for further research. The performance of a start-up is affected by many factors like the product, market conditions, industry and many others. Further analysis that considers these moderating effects could improve our understanding about start-up performance. 
Table 6 Fornell-Larcker criterion

\begin{tabular}{|l|l|l|l|l|}
\hline & $\begin{array}{l}\text { Intention to } \\
\text { cooperate }\end{array}$ & $\begin{array}{l}\text { Cooperation } \\
\text { intensity }\end{array}$ & $\begin{array}{l}\text { Cooperation } \\
\text { quality }\end{array}$ & $\begin{array}{l}\text { Startup } \\
\text { performance }\end{array}$ \\
\hline $\begin{array}{l}\text { Intention to } \\
\text { cooperate }\end{array}$ & 0.789 & 0.743 & & \\
\hline $\begin{array}{l}\text { Cooperation } \\
\text { intensity }\end{array}$ & 0.724 & 0.686 & 0.729 & \\
\hline $\begin{array}{l}\text { Cooperation } \\
\text { quality }\end{array}$ & 0.449 & 0.179 & 0.110 & 0.866 \\
\hline $\begin{array}{l}\text { Startup } \\
\text { performance }\end{array}$ & 0.033 & & & \\
\hline
\end{tabular}

\section{General discussion and conclusion}

\subsection{Summary}

Cooperations with incumbent firms represent an important strategic approach for start-ups. This research provides a key step in developing measurement theory related to start-up cooperation behavior and identifies three behavior dimensions and one performance dimension: intention to cooperate, cooperation intensity, cooperation quality, and start-up performance. The results of the item development process provide a multi-item measurement scale for each dimension. Such dimensions and the full model can be used to evaluate the relationships among cooperation intentions, current behavior, and performance. The results of the first study lend support to the assumption that start-ups with a stronger intention to cooperate are more successful. However, incumbents should incorporate the three dimensions of start-up cooperation behavior during the selection and development of partnerships with start-ups, as such dimensions also affect the performance of the start-upincumbent relationship.

\subsection{Theoretical contributions}

The measurement model addresses the gap caused by missing empirical approaches in current cooperation research regarding entrepreneurial firms. As the literature review shows, some studies do use empirical methods, though there is a lack of analysis of causal models using multi-item scales, although recent research shows that cooperations are essential for a start-up's success $[7,15,31]$. The current study helps filling the addressed research gap and shows results validating the built measurement model and their causal effects.

The concept of a start-up's behavior in cooperation has already been addressed in prior research [20]. Research shows that start-ups' behavior does influence the cooperation outcome and consequently their performance [15]. However, empirical evidence is still scant as a result of a lack of adequate measurement models. The current research takes a first step in building these models, though additional research is still necessary to form a basis that enables researchers to precisely measure start-ups' behavior in cooperation.

\subsection{Practical contribution}

In practice, a start-up's cooperation behavior is a complex mix of various factors. Many influences, such as the industry and age of a start-up, affect behavior and, consequently, its outcome. Further research is necessary to derive practical implications. Potential pathways might uncover tools supporting start-ups and incumbents during the development of mutual relationships. For example, incumbents could adopt measurement metrics to assess a start-up's intention to cooperate. In the future, such metrics might also be applied during the selection of suitable start-ups for viable cooperation. Start-ups can also use such measurement models for self-assessment. This research describes a causal relationship between start-up cooperation behavior and performance. Therefore, start-ups need to evaluate their own intention to cooperate if they are to ensure success. In summary, both sides of a cooperation can use the corresponding measurement models and metrics.

\subsection{Limitations and future research}

As with any research, this study has several limitations. First, the empirical results include only Germany-based start-ups from different industries using different business models. Other contexts deserve research attention, such as a start-up's age, which is an important property for young firms. Second, the scale only provides data from one representative of each start-up. Although in small firms the founder or CEO usually makes decisions and reflects the behavior of the firm, the objective views of these study participants could have biased the results.

In addition to addressing these limitations, future research could focus on start-ups from specific industries (e.g. the finance industry) in which start-ups seemingly rely more on their partners because of a highly regulated market. Moreover, cooperations are 
complex constructs of various intensity and goals. By considering only its theoretical definition, a buyerseller relationship could be deemed a cooperation [34]. Therefore some cooperations are more intense than others. As a start-up may enter into many cooperations during its lifetime, future research might focus on one specific cooperation to measure the start-up's behavior.

Finally, to ensure start-up success, many factors are relevant for developing the right business model. Engaging in the right cooperations is just one of them.

In conclusion, this study examines the conceptualization of start-up cooperation behavior and its performance. Scholars should continue investigating cooperation activities of start-ups and its implications for entrepreneurs.

\section{References}

[1] Babin, B.J., W.R. Darden, and M. Griffin, "Work and/or Fun: Measuring Hedonic and Utilitarian Shopping Value", Journal of Consumer Research 20(4), 1994, pp. 644-657. [2] Di Berardino, D., "Corporate Governance and Firm Performance in New Technology Ventures", Procedia Economics and Finance 39(November 2015), 2016, pp. 412 421.

[3] Brown, T.A., Confirmatory factor analysis for applied research., 2006.

[4] Buckley, P.J., and S. Prashantham, "Global Interfirm Networks: The Division of Entrepreneurial Labor Between MNEs and SMEs", Academy of Management Perspectives 30(1), 2016, pp. 40-58.

[5] Colombo, M.G., L. Grilli, and E. Piva, "In search of complementary assets: The determinants of alliance formation of high-tech start-ups", Research Policy 35(8 SPEC. ISS.), 2006, pp. 1166-1199.

[6] Das, T.K., and I.Y. He, Entrepreneurial firms in search of established partners: review and recommendations, 2006. [7] Dowling, M., and R. Helm, "Product development success through cooperation: A study of entrepreneurial firms", Technovation 26(4), 2006, pp. 483-488.

[8] Edison, H., N.M. Smørsgård, X. Wang, and P. Abrahamsson, "Lean Internal Startups for Software Product Innovation in Large Companies: Enablers and Inhibitors", Journal of Systems and Software 135, 2018, pp. 69-87. [9] De Faria, P., F. Lima, and R. Santos, "Cooperation in innovation activities: The importance of partners", Research Policy 39(8), 2010, pp. 1082-1092.

[10] Gerbing, D.W., and J.C. Anderson, “An Updated Paradigm for Scale Development Incorporating Unidimensionality and Its Assessment”, Journal of Marketing Research 25(2), 1988, pp. 186.

[11] Hagedoorn, J., B. Lokshin, and S. Malo, "Alliances and the innovation performance of corporate and public research spin-off firms", Small Business Economics 50(4), 2017, pp. 763-781.

[12] Hair, J.F., A primer on partial least squares structural equation modeling (PLS-SEM), 2015.

[13] Henseler, J., C.M. Ringle, and R.R. Sinkovics, "The use of partial least squares path modeling in international marketing", In Advances in International Marketing. 2009, 277-319.

[14] Hockerts, K., and R. Wüstenhagen, "Greening Goliaths versus emerging Davids - Theorizing about the role of incumbents and new entrants in sustainable entrepreneurship", Journal of Business Venturing 25(5), 2010, pp. 481-492.

[15] Islam, N., P. Buxmann, and D. Ding, "Fostering Digital Innovation Through Inter-Organizational Collaboration Between Incumbent Firms and Start-Ups", Proceedings of the 25th European Conference on Information Systems (ECIS) 2017, 2017, pp. 1029-1043.

[16] Kim, J.H., and L. Wagman, "Portfolio size and information disclosure: An analysis of startup accelerators", Journal of Corporate Finance 29, 2014, pp. 520-534.

[17] Kohler, T., "Corporate accelerators: Building bridges between corporations and startups", Business Horizons 59(3), 2016, pp. 347-357.

[18] Malek, K., E. Maine, and I.P. McCarthy, "A typology of clean technology commercialization accelerators", Journal of Engineering and Technology Management - JET-M 32, 2014, pp. 26-39.

[19] Minshall, T., L. Mortara, S. Elia, and D. Probert, "Development of practitioner guidelines for partnerships between start-ups and large firms", Journal of Manufacturing Technology Management 19(3), 2008, pp. 391-406.

[20] Oukes, T., and A. Von Raesfeld, A start-up in interaction with its partners, 2016.

[21] Pauwels, C., B. Clarysse, M. Wright, and J. Van Hove, "Understanding a new generation incubation model: The accelerator", Technovation 50-51, 2016, pp. 13-24.

[22] Perez, L., J. Whitelock, and J. Florin, "Learning about customers", European Journal of Marketing 47(3/4), 2013, pp. 431-462.

[23] Rauschnabel, P.A., N. Krey, B.J. Babin, and B.S. Ivens, "Brand management in higher education: The University Brand Personality Scale", Journal of Business Research 69(8), 2016, pp. 3077-3086.

[24] Ries, E., The lean startup how today's entrepreneurs use continuous innovation to create radically successful businesses, Currency, New York, 2011.

[25] Ringle, C.M., M. Sarstedt, and D.W. Straub, "Editor's Comments: A Critical Look at the Use of PLS-SEM in 'MIS Quarterly"”, MIS Quarterly 36(1), 2012, pp. iii--xiv.

[26] Rothaermel, F.T., "Technological discontinuities and interfirm cooperation: What determines a startup's attractiveness as alliance partner?", IEEE Transactions on Engineering Management 49(4), 2002, pp. 388-397.

[27] Schryen, G., "Writing qualitative is literature reviewsGuidelines for synthesis, interpretation, and guidance of research", Communications of the Association for Information Systems 37, 2015, pp. 286-325.

[28] Steve Blank, "What's A Startup? First Principles.", 2010, 1. https://steveblank.com/2010/01/25/whats-a-startupfirst-principles/

[29] Tenenhaus, M., V.E. Vinzi, Y.-M. Chatelin, and C. Lauro, "PLS path modeling", Computational Statistics \& Data Analysis 48(1), 2005, pp. 159-205.

[30] Tomlinson, P.R., "Co-operative ties and innovation: Some new evidence for UK manufacturing", Research Policy 39(6), 2010, pp. 762-775. 
[31] Usman, M., and W. Vanhaverbeke, "How start-ups successfully organize and manage open innovation with large companies", European Journal of Innovation Management 20(1), 2017, pp. 171-186.

[32] Webster, J., and R.T. Watson, "Analyzing the Past to

Prepare for the Future: Writing a Literature Review.", MIS Quarterly 26(2), 2002, pp. xiii-xxiii.
[33] Weiblen, T., and H.W. Chesbrough, "Engaging with Startups to Enhance Corporate Innovation", California Management Review 57(2), 2015, pp. 66-90.

[34] Williams, T., "Cooperation by design: Structure and cooperation in interorganizational networks", Journal of Business Research 58(2 SPEC.ISS.), 2005, pp. 223-231. 